\title{
Fenomena Penggunaan Kayu pada Rumah Tradisional di Tepus, Gunungkidul, D.I Yogyakarta
}

\author{
Anggoro Cipto Ismoyo a, 1, Satrio Hasto Broto Wibowo b, 2
}

a Universitas Telkom, Jl. Telekomunikasi, Sukapura, Dayeuhkolot, Bandung, Jawa Barat 40257

b Universitas Widya Mataram, KT III/237, Jalan Dalem Mangkubumen, Kadipaten, Kecamatan Kraton, Kota Yogyakarta, Daerah Istimewa Yogyakarta 55132

1 anggoroismoyo@telkomuniversity.ac.id; 2 satriohb@ymail.com

\begin{tabular}{ll}
\hline Informasi artikel & ABSTRAK \\
\hline Sejarah artikel: & Penelitian ini bertujuan untuk menggali konsep dan nilai-nilai lokal \\
Diterima & tentang fenomena penggunaan kayu pada rumah-rumah tradisional di \\
Revisi & Tepus, Gunungkidul, Daerah Istimewa Yogyakarta. Pendekatan penelitian \\
Dipublikasikan & yang digunakan adalah fenomenologi. Dalam prosesnya, peneliti terlibat \\
\hline Kata kunci: & langsung di lapangan untuk mengenali, menggali, dan mengumpulkan \\
nilai lokal & informasi sebanyak mungkin dari objek maupun sumber-sumber informasi \\
penggunaan kayu & di lapangan, sehingga ditemukan tema-tema. Tema-tema tersebut \\
rumah tradisional & kemudian dianalisis kedalam kategori-kategori sehingga dapat dikenali \\
Tepus & pola-pola umumnya untuk diintepretasikan dalam suatu konseptualisasi \\
fenomenologi & melalui generalisasi untuk memperoleh tujuan penelitian. Hasil penelitian \\
& menunjukan bahwa fenomena tentang penggunaan kayu pada rumah \\
& tradisional di Tepus dipengaruhi oleh nilai-nilai ekonomis, pengetahuan \\
lokal, dan religi.
\end{tabular}

Copyright (C) 2018 Universitas Widya Mataram Yogyakarta. All Right Reserved

\section{Pendahuluan}

Arsitektur tradisional merupakan bagian kehidupan dari masyarakat yang memiliki tinggi nilainilai keluhuran, tak lepas dari cara ataupun kebiasaan yang sudah ada terdahulu. Tradisi adalah sebuah kegiatan yang dilakukan secara terus-menerus, berulang-ulang, atau sebuah kebudayaan atau sebuah hasil karya yang dianggap berhasil dan memiliki legitimasi dalam kurun waktu yang cukup panjang dan bahkan sangat panjang, yang diikuti oleh generasi generasi berikutnya secara turun temurun (Harpioza, 2016:). Sebagaimana menurut Rapoport (1994, dalam Sardjono dan Nugroho, 2015), tradisi mempunyai makna nilai atau aturan yang dipatuhi dalam kurun waktu yang lama dan diturunkan secara lisan antar generasi. Mempelajari arsitektur tradisional berarti turut berperan dalam upaya pelestarian kebudayaan, bukan sekadar dalam wujud artefak, namun pula nilai-nilai, pengetahuan, dan kearifan, yang dapat digunakan sebagai referensi antar generasi, untuk diambil manfaatnya secara keilmuan maupun praktis sesuai dengan konteks dan kebutuhan di masa kini maupun mendatang.

Penelitian ini dilakukan di wilayah Kecamatan Tepus, Kabupaten Gunungkidul, Daerah Istimewa Yogyakarta dengan karakteristik sosial budaya masyarakat Gunungkidul yaitu masyarakat tradisional yang masih memegang teguh budaya luhur warisan nenek moyang (Badan Perencanaan Pembangunan Dearah, 2012). Menurut Mixdam (2017), Gunungkidul merupakan salah satu daerah yang masih memegang erat hal-hal yang bersifat kebudayaan salah satunya adalah upacara adat. Upacara adat yang sampai sekarang masih tetap dilakukan setiap tahunnya adalah rasulan. Keunikan karakter wilayah, 
tradisi, maupun nilai-nilai lokal merupakan potensi menarik untuk digali yang kemudian membawa pada eksplorasi tentang proses dan hasil kebudayaan lain yang pada umumnya dimiliki pula secara khas yakni berarsitektur.

Dalam konteks berarsitektur, Salura (2001) mengidentifikasi empat kegiatan yang saling terkait, yaitu membuat, menggunakan, mengalami, dan memahami arsitektur. Keempat kegiatan tersebut tidak harus selalu berjalan berurutan secara linier, tetapi bisa tumpang tindih satu sama lain, serempak, atau siklus ulang. Berdasarkan konteks tersebut, maka dapat dikemukakan bahwa berarsitektur mengandung suatu proses, selain menghasilkan suatu produk ataupun menjadi sebuah artefak, dapat pula menghasilkan pengetahuan-pengetahuan dan pengalaman yang dapat diwariskan, diajarkan, ataupun dikembangkan. Proses dinamis yang dijalani ataupun yang dialami oleh masyarakat yang memegang tradisi, dalam kaitannya dengan berarsitektur merupakan hal yang perlu diungkap sebagai kearifan lokal. Beberapa penelitian tentang arsitektur rumah tradisional secara umum telah memberikan sumbangsih pengetahuan tentang ragam wujud serta aspek-aspek yang mempengaruhi pembentukannya. Sementara itu, penyelidikan tentang proses perwujudan arsitektur tradisional, termasuk di dalamnya tentang pemilihan material untuk konstruksinya masih belum banyak dilakukan.

Rumah sebagai wadah aktivitas akan mencerminkan kegiatan keseharian dari penghuninya. Keseharian kegiatan yang terpola pada masyarakat tersebut mencerminkan gaya hidup masyarakat dan gaya hidup masyarakat ini adalah cerminan nilai-nilai yang berlaku di masyarakat tersebut (Sardjono dan Nugroho, 2015). Secara umum, rumah tradisional di Kecamatan Tepus mengacu pada rumah tradisional Jawa. Wibowo (2013) meneliti tentang arsitektur rumah tradisional di Tepus yang dikenal dengan Omah Bunder, menyatakan bahwa terdapat fenomena-fenomena yang khas yang belum terkuak hingga kini, sehingga masih menjadi pengetahuan arsitektur yang tersembunyi. Menurut Subroto (2019), eksplorasi terhadap fenomena arsitektur hingga bermuara pada diketahuinya makna simbolik yang termuat di dalamnya perlu dilakukan melalui proses panjang. Secara umum dikatakan bahwa proses memahami alam dan budaya masyarakat diperoleh melalui proses eksplorasi yang mendalam untuk menguraikannya. Hal ini dilakukan karena makna simbolis dan nilai filosofis kebudayaan setempat telah menyatu secara inheren atau bersenyawa dengan bangunannya. Nilai intrinsik kepercayaan dan mitos yang terkandung dalam kebudayaan telah memperkuat konsep dan menyatu dengan proses konstruksi bangunan khususnya pada kasus bangunan tradisional.

Bagi orang Jawa, termasuk mereka yang tinggal di Daerah Istimewa Yogyakarta, pada saat menentukan usaha untuk mendirikan bangunan selalu mempertimbangkan tiga masalah, pertama tempat di mana bangunan tempat tinggal itu akan didirikan, kedua bahan-bahan yang digunakan untuk bangunan itu dan ketiga masalah saat kapan sebaiknya dimulai pekerjaan mendirikan bangunan tempat tinggal atau rumah itu. Tiga masalah pokok inilah merupakan pemikiran bagi setiap orang Jawa bilamana hendak mendirikan bangunan sebagai tempat tinggalnya (Wibowo, J, dkk, 1998). Demikian pula dalam penelusuran awal tentang rumah tradisional di Tepus, dapat terungkap informasi tentang material kayu untuk konstruksi bangunan tersebut, bukan sekadar jenis dan ragamnya tetapi juga fenomena-fenomena yang menyertai pemilihan dan penggunaannya. Penyelidikan tentang penggunaan kayu pada arsitektur tradisional di Tepus menjadi bagian yang penting untuk dilakukan karena merupakan bagian dari proses berarsitektur oleh masyarakat yang masih memegang nilai-nilai tradisinya. Hasil penelitian dapat melengkapi penelitian-penelitian yang sebelumnya tentang arsitektur rumah tradisional, khususnya di wilayah Tepus, ataupun secara umum dalam kaitan dengan penyelidikan tentang arsitektur rumah tradisional.

\section{Metode}

Pendekatan penelitian yang dipilih dalam penelitian ini bersifat kualitatif yaitu fenomenologi, sesuai dengan tujuan untuk mengungkap nilai-nilai lokal berdasarkan fenomena serta pengalaman yang terjadi pada masyarakat, dalam hal ini kaitannya dengan arsitektur rumah tradisional di Tepus. Menurut Jonathan dalam Gunawan (2013), fenomenologi sebagai sebuah filsafat yang menekankan pada pengalaman individual, dengan tujuan menghasilkan sebuah dasar pengetahuan yang kokoh, sangat berpengaruh pada arsitektur. Hal ini dikarenakan oleh penekanan fenomenologi pada persepsi dan kognisi yang terhasil darinya. Sebagaimana menurut Creswell (2013), fenomenologi adalah penelitian yang mendeskripsikan mengenai pengalaman atau fenomena yang dialami oleh seseorang. Dengan pendekatan fenomenologi, penelitian dapat dilakukan dalam seting alamiah, yaitu individu tidak 
terpisahkan dari konteks lingkungannya. Artinya, fenomena-fenomena subjek tidak dicampurkan dengan fenomena lain yang tidak berhubungan, atau tidak diitervensi oleh interpretasi-interpretasi lain yang berasal dari kebudayaan, kepercayaan, atau bahkan dari teori-teori dalam ilmu pengetahuan yang telah peneliti miliki sebelumnya. Anisa (2010), dalam kajiannya terhadap aplikasi paradigma fenomenologi dalam penelitian arsitektur, menyampaikan bahwa fenomenologi memungkinkan sebuah penelitian berada tetap dalam konteks naturalnya serta tidak bertujuan untuk membuat generalisasi. Teori-teori lokal akan dimunculkan dari penelitian dengan paradigma fenomenologi tersebut.

Penelitian dilakukan di wilayah Kecamatan Tepus, Kabupaten Gunungkidul yang secara administratif terletak di sebelah tenggara Kota Yogyakarta (Ilustrasi lokasi penelitian ditunjukkan pada Gambar 1). Jarak Wonosari dengan Kota Yogyakarta adalah \pm 39 kilometer. Wilayah Kabupaten Gunungkidul terletak antara 7o46'- 8o09' Lintang Selatan dan 110o 21' - 110o50' Bujur Timur, yang berbatasan dengan Kabupaten Klaten, Kabupaten Sukoharjo, Jawa Tengah di sebelah Utara, Kabupaten Wonogiri, Jawa Tengah di sebelah Timur, Samudra Indonesia di sebelah Selatan dan Kabupaten Bantul, Kabupaten Sleman, DI Yogyakarta di sebelah Barat (Badan Pusat Statistik Kabupaten Gunungkidul, 2019).
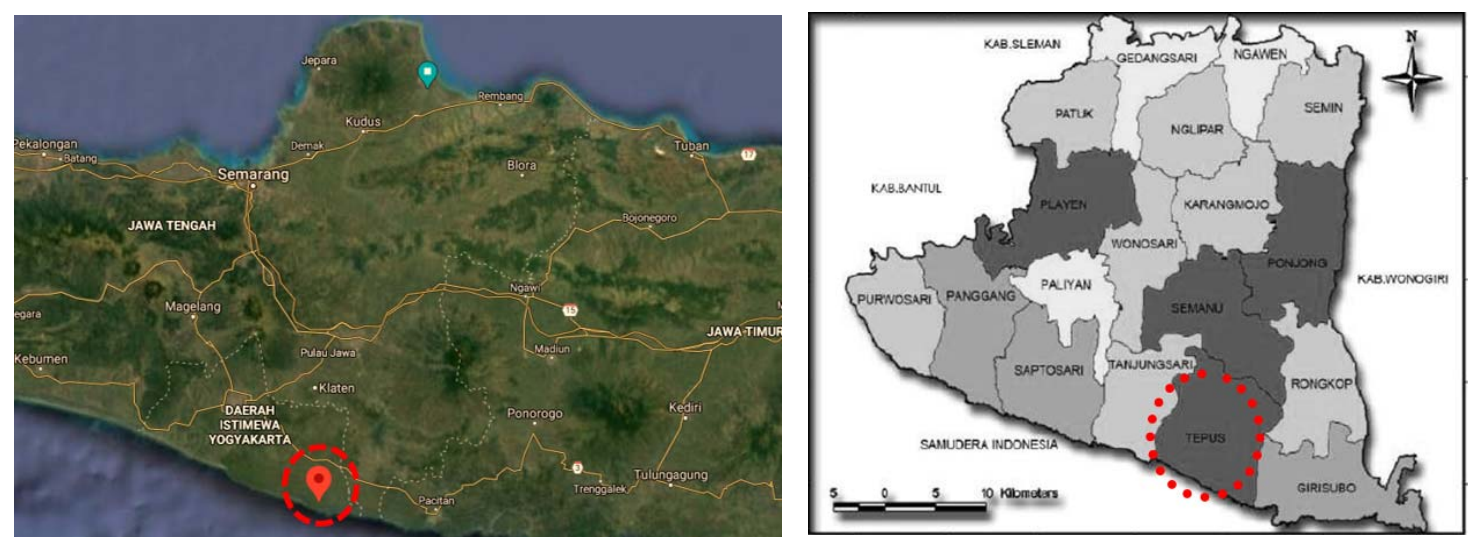

Gambar 1. Lokasi Penelitian di Tepus berdasarkan Citra Satelit (kiri), dan Ilustrasi Wilayah Lokasi Penelitian pada Peta Administratif D.I Yogyakarta (kanan)

(Sumber: olah citra satelit Google-Earth dan olah dokumentasi oleh penulis, 2020)

Sesuai paradigma fenomenologi yang digunakan, maka instrumen penelitian yang digunakan dalam penelitian ini adalah peneliti sendiri, atau peneliti merupakan alat penelitian. Peneliti terlibat langsung di lapangan untuk menangkap, menggali, dan mengumpulkan informasi sebanyak mungkin dari objek lapangan maupun sumber-sumber informasi. Peneliti hanya membawa pengetahuan sebagai background knowledge dalam upaya menangkap dan menggali informasi tentang fenomena-fenomena di lapangan. Peneliti mengkaji sejumlah objek dengan turun langsung ke lapangan, terlibat secara langsung dalam kurun waktu tertentu untuk mengembangkan pola-pola dan relasi-relasi makna. Dalam hal ini peneliti mengesampingkan terlebih dahulu pengalaman-pengalaman pribadinya agar dapat memahami pengalaman-pengalaman partsipan yang diteliti.

Sebagaimana menurut Cresswell (2013) proses penelitian kualitatif ini melibatkan upaya-upaya penting, seperti mengajukan pertanyaan-pertanyaan dan prosedur-prosedur, mengumpulkan data yang spesifik dari partisipan, menganalisis data secara induktif mulai dari tema-tema yang khusus ke tematema umum, dan menafsirkan makna data. Untuk membantu proses tersebut, peneliti didukung oleh beberapa alat, antara lain: kamera digital, alat perekam suara, alat tulis, dan buku catatan. Penelitian ini menggunakan sampel purposive, yakni bahwa sampel yang dipilih berorientasi pada tujuan penelitian. Teknik wawancara yang dilakukan peneliti adalah dengan cara berbincang dengan para informan tanpa membawa referensi teori dan topik spesifik yang telah disiapkan, melainkan dengan menanggapi 
pembicaraan berdasarkan ungkapan ataupun informasi yang disampaikan oleh informan, kemudian direkam dan dicatat dalam buku catatan (logbook). Dalam proses analisis dalam penelitian ini, setiap unit informasi dan kasus dieksplorasi untuk memunculkan tema-tema. Tema-tema temuan tersebut kemudian dianalisis ke dalam kategori-kategori untuk ditemukan pola-pola umum. Dari pola-pola umum tema tersebut kemudian dikemukakan suatu konsep melalui generalisasi.

Untuk mendapatkan gambaran awal, dilakukan pertemuan di rumah Bapak Sudarli sebagai Kepala Dusun setempat. Dalam pertemuan tersebut didapatkan informasi mengenai hal-hal yang dapat ditelusuri lebih lanjut mengenai tradisi dan budaya yang berlaku di kawasan Tepus. Peneliti lalu melakukan grandtour untuk memperoleh gambaran awal dari lapangan dan akan mengambil fokus penelitian berdasarkan tujuan dan ketertarikan peneliti dari temuan-temuan informasi di lapangan. Bahasa yang digunakan oleh masyarakat di lokasi penelitian didominasi dengan Bahasa Jawa, sehingga beberapa istilah ditulis dalam Bahasa Jawa, dengan ataupun tanpa alih bahasa ke Bahasa Indonesia guna menunjukkan keaslian informasi yang didapatkan dari unit informasi.

Berdasarkan hasil observasi singkat dan perbincangan awal dengan para narasumber, maka penelitian ini kemudian difokuskan pada konsep-konsep penggunaan material bangunan pada rumah tradisional di Tepus, khususnya penggunaan material kayu. Beberapa informasi diperoleh dari unit-unit informasi yang terdiri dari rumah-rumah para informan (dengan ilustrasi lokasi rumah sesuai angka pada Gambar 2) yaitu:

1. Bapak Bambang (55 tahun), warga Dusun Pringsanggar, Tepus

2. Bapak Poncorejo (76 tahun), warga Dusun Pringsanggar, Tepus

3. Bapak Mintoredjo (90 tahun), warga Dusun Pringsanggar, Tepus

4. Bapak Sastrowiharjo (86 tahun), warga Dusun Ngandong, Tepus

5. Bapak Sudarli (62 tahun), warga Dusun Pringsanggar, Tepus

6. Bapak Hartono (60 tahun), warga Dusun Pringsanggar, Tepus

7. Bapak Karyo (92 tahun), warga Dusun Cepogo, Tepus

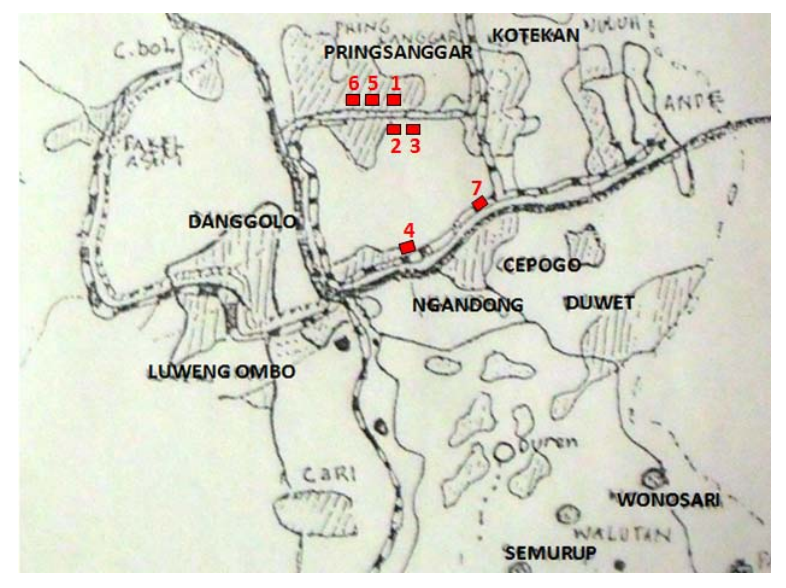

Gambar 2. Posisi Rumah Para Informan

(Sumber: ilustrasi dan olah dokumentasi Penulis, 2020)

\section{Hasil dan pembahasan}

\section{Fokus Penelitian berdasarkan Informasi Awal dan Grandtour}

Berdasarkan penelusuran awal pada lingkungan dan rumah-rumah di wilayah Kecamatan Tepus, maka secara umum dapat dikelompokkan menjadi tiga jenis, yakni, 1) Rumah tradisional; 2) Rumah tradisional dengan perubahan; dan 3) Rumah modern. Yang dimaksud dengan rumah tradisional 
tersebut sebagaimana hasil preferensi awal mengacu pada jenis rumah tradisional Jawa, yang disebut sebagai "Omah Bunder". Sementara yang dimaksud dengan rumah modern, berdasarkan hasil penelusuran awal adalah rumah yang menggunakan bentuk tidak sebagaimana rumah tradisional, dengan konstruksi yang modern, serta dominan menggunakan material yang lebih permanen seperti halnya bata, besi, dan semen. Berdasarkan preferensi tersebut, maka peneliti memutuskan mengambil fokus dan objek amatan pada rumah tradisional, sehingga informasi-informasi yang diambil dari rumah dan informan yang menghuni rumah tradisional di Tepus.

\section{Temuan Tema dari Unit Informasi I}

Unit informasi I (pertama) diperoleh di kediaman keluarga Bapak Bambang, dengan Bapak Bambang sebagai informan yang ditentukan sebagai Informan I. Rumah Bapak Bambang merupakan warisan dari orangtua beliau, sehingga hitungan pecakan berdasarkan milik orangtua beliau. Rumah yang ditempati Bapak Bambang merupakan Omah Bunder, berbahan kayu Jati, kecuali pada bagian usuk dan reng pada bagian atap yang menumpu pada bagian atap ke dinding tepi yang menggunakan kayu taun. Menurut Informan I, sebelumnya posisi usuk-usuk tersebut sama, yakni dengan sisi terpanjang menghadap ke bawah, sebagai tumpuan, namun seiring waktu dibongkar dan diganti dengan kayu yang berbeda. Alasan posisi hadap usuk untuk menumpu ditentukan dari arah rubuh kayu. Dikatakan oleh Informan I, rumah akan memberikan pengaruh kepada ketentraman pada penghuni. Oleh sebab itu, dalam membangun rumah tidak boleh sembarangan atau sekedar wujud, namun membutuhkan persyaratan, tentang waktu pendirian, bahkan jenis kayu dan proses penebangan pohon. Hal tersebut dimaksudkan karena rumah adalah warisan yang harus dijaga antar generasi.

Dalam hal penggunaan kayu untuk membangun rumah, terdapat tata cara dalam menebang dan memilih kayu. Sebelum menebang, pohon harus diteres terlebih dahulu, yakni dengan mengurangi lapisan batang pohon bagian bawah hingga kambium. Hal tersebut dilakukan dengan tujuan agar pohon perlahan mati dan mengering, sehingga memudahkan dalam penebangan dan diperoleh kayu yang telah kering. Yang perlu diperhatikan adalah cacat pada kayu sehingga kayu tersebut termasuk pada jenis kayu yang tidak baik untuk digunakan sebagai bahan bangunan. Apabila kayu-kayu yang memiliki 'cacat' tersebut digunakan pada bangunan, terutama konstruksi utama (tiang empat dan tiang delapan) maka akan memberi dampak yang tidak baik pada penghuni. Dampak yang tidak baik tersebut contohnya adalah mudah timbul percekcokan, ketidaktentraman dalam rumah, ataupun penghuni sering sakit. Apabila yang menggunakan tidak tahu tentang mana posisi ujung dan pangkal kayu setelah ditebang, yang dapat disebabkan karena yang menebang adalah orang lain atau memperoleh dari membeli, maka posisi tersebut dapat diketahui dengan cara menimbang. Dari hasil penimbangan akan diketahui bahwa bagian kayu yang memiliki berat lebih adalah bagian pangkal, dan sebaliknya yang paling ringan adalah bagian ujung. Jika suatu ketika terpaksa, lalu menggunakan bahan kayu tersebut pada rumah, maka harus ditebus dengan persyaratan sedekah melaui suatu upacara yang dipimpin oleh seorang yang dianggap sebagai Kyai. Pada upacara tersebut akan disampaikan permohonan maaf dan doa kepada Tuhan Yang Maha Esa agar memberikan keselamatan untuk seterusnya. Sedekah dalam prosesi tersebut terdiri dari: tumpeng, jajanan pasar, lawon putih (kain mori), dan bermacam-macam jenang.

Menurut Informan I, keberadaan kayu Jati sebenarnya sudah ada sejak zaman penjajah Jepang namun disembunyikan agar tidak dirampas oleh Jepang untuk membiayai perang. Termasuk apabila membenci orang, keberadaan kayu dapat digunakan untuk menjebak orang yang dibenci dengan jalan menaruh kayu tersebut di depan rumah, kemudian di laporkan kepada yang berwenang (Mandor kayu) agar ditangkap. Dengan demikian bila kayu diperoleh dari membeli di pasar Dakbong dikatakan dari Cepu, hal tersebut dinilai sebagai strategi agar nilainya meningkat. Kayu-kayu yang dijual di pasar Dakbong waktu itu sekitar tahun 1970 juga merupakan pesanan bagi yang akan membangun rumah. Untuk kayu Jati yang dinilai berkualitas pada waktu itu, didapatkan dengan membeli meskipun tidak resmi (ilegal) atau dapat dinilai sebagai 'mencuri' dengan jalan kolusi dengan Mandor. Kayu tersebut sebenarnya berasal dari hutan yang ditanam di tanah $\mathrm{AB}$. Tanah $\mathrm{AB}$ tersebut mulanya tidak dimiliki oleh siapapun. Menurut Informan I, semenjak masa Sultan II, tanah tersebut ditanami dengan pohon 
Jati dengan maksud apabila suatu saat Keraton membutuhkan perbaikan, maka kayu-kayu tersebut dapat digunakan. Dalam hal ini, yang dimaksud dengan $\mathrm{AB}$ aslinya adalah HB yang merupakan kependekan dari Hamengku Buwono, sehingga tanah HB adalah tanah milik Sultan atau Sultan Ground. Lokasi tanah AB berada di dekat Pantai Siung dengan luas lebih kurang 70 hektar. Kayu-kayu (dari hutan) tersebut lalu habis dirampas oleh Jepang, meskipun ada kayu yang 'luar biasa' karena diangkut dengan mobil tidak mampu, bukan karena ukurannya (dimensinya), tapi disebabkan oleh (kekuatan) 'keyakinan'. Kayu tersebut dapat diangkut setelah ada sesepuh yang menangani.

Informan I menuturkan bahwa keberadaan rumah yang dinilai masih dalam kondisi baik saat ini, dengan menggunakan kayu yang baik, karena pendahulunya memiliki kedudukan yang tinggi di masyarakat, baik karena keilmuan yang dimiliki maupun karena geng (kelompok yang disegani). Hal tersebut terkait dengan cara memperoleh kayu, yaitu orang-orang yang dapat melakukan kerjasama untuk memperoleh kayu adalah mereka yang disegani ataupun punya kedudukan di masyarakat. Dalam proses memperoleh kayu, yang dinilai curang sebenarnya adalah tukang yang menebang. Suatu misal kebutuhan untuk membangun rumah cukup dengan 4 (empat) hingga 5 (lima) batang pohon, namun tukang menebang lebih banyak, kemudian disembunyikan di luweng (lubang tanah yang terbentuk alami). Maka seandainya zaman sekarang diupayakan cara untuk menggali tanah tersebut akan ditemukan Jati dengan kualitas tinggi yang tidak lapuk oleh air maupun tanah. Tentang 'pencurian' kayu tersebut sebenarnya diketahui oleh Sultan, akan tetapi karena kebijaksanaan seorang raja, maka kejadian tersebut dimaklumi dengan alasan bahwa tanah tersebut berada di daerah (warga yang mencuri), yang mengambil adalah punggawa (rakyat) sendiri untuk kebutuhan mereka sendiri, dan di tempat lain juga masih ada. Meskipun kayu yang dibeli kemudian digunakan kemungkinan hasil dari hasil pencurian, dikatakan tidak memberikan efek dengan dalih tidak tahu asal-muasalnya secara pasti.

Berdasarkan informasi yang diberikan dari Informan I, maka tema-tema yang dapat diperoleh sebagai Unit Informasi I adalah:

1. Penerapan kayu, yakni penentuan posisi kayu berdasar kondisi rubuh kayu

2. Cara menebang kayu, diawali dengan diteres (mengurangi lapisan cambium)

3. Jenis-jenis kayu yang dinilai tidak baik

4. Dampak atau efek penggunaan kayu yang tidak baik

5. Cara mengetahui ujung-pangkal kayu

6. Syarat untuk 'menebus' kayu yang tidak baik dapat ditempuh dengan ritual adat dan 'sedekah'

7. Asal-muasal (lokasi dan kepemilikan) kayu, yakni tanah HB milik Sultan

8. Cara-cara memperoleh kayu pada zaman pendahulu

9. Pengaruh kedudukan atau status sosial dalam perolehan kayu

10. Pengaruh kekuatan keyakinan dalam 'penjagaan' kayu

\section{Nilai ekonomis kayu}

\section{Temuan Tema dari Unit Informasi II}

Unit informasi II (kedua) diperoleh di kediaman keluarga Bapak Poncorejo, dengan Bapak Poncorejo sebagai informan II. Rumah yang ditinggali oleh Bapak Poncorejo dan istrinya diperoleh dari hasil membeli. Rumah tersebut dibangun sekitar tahun 1940, saat Jepang masih menjajah Indonesia, dan dibeli pada tahun 1963 dari warga Kotekan dan sudah berwujud rumah atau siap ditempati. Bahan kayu yang mendominasi rumah tersebut adalah kayu Jati, kecuali pada dinding samping yang sudah diganti dengan batu-bata, dan elemen usuk yang ada yang menggunakan bambu. Gebyok pada rumah tersebut juga terbuat dari kayu Jati yang diperoleh dengan jalan membeli kayu, kemudian diangkut dengan cara digotong bersama, lalu dikerjakan oleh tukang. 
Kayu untuk konstruksi rumah diperoleh dari hutan sebelah selatan yang merupakan kayu Jati HB, milik dari Sultan Hamengkubuwono yang waktu itu tinggal di dekat pantai setempat. Dalam menggunakan kayu untuk bangunan dalam tradisi Jawa, sebaiknya sama, baik dalam jenis maupun ukuran besar ataupun kecilnya. Hal tersebut berlaku untuk cagak (tiang), blandar, dan pengeret. Sebagai contoh, apabila cagak (tiang) dengan blandar dan pengeret, apabila yang lebih besar cagak akan diistilahkan "tadah luh" yang memberi daya kesusahan. Sementara itu, bahan yang digunakan untuk usuk, reng maupun gebyok diperbolehkan menggunakan kayu bahan lainnya.

Menurut Informan II, ada tiga kayu yang dicontohkan, yaitu kayu Jati, kayu Nangka, dan kayu Taun, yang masing-masing kayu tersebut memiliki 'pemelihara' yakni:

1. Manukma Kesuma Sejati yang mengku kayu Jati

2. Manukma Kesuma Jati Aking, yang mengku kayu Nangka

3. Manukma Kesuma Jati Awal, yang mengku kayu Taun

Untuk kayu Jati dilarang digunakan bersama kayu Nangka karena berakibat tidak akur, yakni memberi daya atau efek bertengkar (bagi penghuni).

Berdasarkan informasi yang diberikan dari Informan II, maka tema-tema yang dapat diperoleh sebagai Unit Informasi II adalah:

1. Asal perolehan kayu, yakni Jati dari milik HB yang tinggal dekat pantai setempat

2. Penggunaan kayu sebaiknya sama untuk cagak, blandar, pengeret, sementara pada gebyok, usuk maupun reng boleh terserah.

3. Pantangan dalam penggunaan kayu (Jati dan Nangka)

4. Pemilihan kayu memberi dampak tertentu bagi penghuni, tentang besar-kecil, serta jenis kayu yang digunakan

5. Menurut kepercayaan, kayu Jati, Nangka, maupun Taun, masing-masing ada yang ngemong (memelihara atau menjaga)

\section{Temuan Tema dari Unit Informasi III}

Unit informasi III (ketiga) diperoleh di kediaman keluarga Bapak Mintorejo, dengan Bapak Mintorejo sebagai informan III. Bapak Mintorejo memiliki rumah tersebut berasal dari warga Balong dengan cara membeli. Bahan kayu di rumah tersebut didominasi oleh kayu Jati kecuali bagian gebyok yang berasal dari kayu Akasia. Gebyok tersebut masih relatif baru, yakni 2 (dua) tahun yang proses pengerjaannya dikerjakan sendiri.

Bahan kayu Jati untuk membuat rumah tersebut berasal dari Cepu yang dibeli dari pasar Dakbong. Kayu tersebut diperoleh dari Cepu karena pada zaman rumah tersebut dibangun, daerah sekitar belum terdapat kayu Jati. Kayu yang banyak terdapat di daerah tersebut adalah jenis kayu Sengon dan Weru. Meskipun pada zaman tersebut berharga mahal, kayu Jati menjadi pilihan Informan III dengan alasan keawetan.

Berdasarkan informasi yang diberikan dari Informan III, maka tema-tema yang dapat diperoleh sebagai Unit Informasi III adalah:

1. Bahan kayu yang digunakan pada konstruksi rumah didominasi kayu Jati, kecuali pada elemen gebyok

2. Perolehan kayu Jati berasal dari luar daerah, yaitu Cepu

3. Pertimbangan pemilihan kayu Jati karena keawetan, meskipun harganya mahal 


\section{Temuan Tema dari Unit Informasi IV}

Unit informasi IV (keempat) diperoleh di kediaman keluarga Bapak Sudarli, dengan Bapak Mintorejo sebagai Informan IV. Menurut Informan IV, bagi orang Jawa, penggunaan kayu Jati dan kayu Nangka pada konstruksi rumah merupakan suatu pantangan. Pantangan tersebut didasarkan alasan jika suatu ketika kedua kayu (Jati dan Nangka) dimakan oleh teter (sejenis organisme pemakan kayu), maka akan (senyawa) keduanya dapat menghasilkan racun yang menjadikan orang yang menghuni rumah seperti terkena tenung (sihir) atau mudah sakit. Kayu Jati dan kayu Nangka bila digunakan bersama akan menimbulkan bunyi keras, sebagaimana pengalaman yang dialami pada rumah informan yang sebelumnya pernah menggunakan keduanya secara bersama.

Menurut Informan IV, ciri-ciri kayu yang dinilai tidak baik antara lain: buntel mayit, kelabang kepipit, podang angkrik, dan kongakangean. Oleh sebab itu, saat menebang kayu harus diperhatikan dan diarahkan agar tidak menjadi sundang angkrik atau sundang kongakangean. Untuk mengetahui ciriciri kayu yang tidak baik tersebut tidaklah sulit. Bila ternyata terlanjur digunakan, umumnya setelah mengetahui akan kecewa. Apabila suatu kayu diketahui memiliki ciri yang tidak baik, misalnya "buntel mayit”, maka kayu dapat digunakan dengan cara membuang bagian yang menjadikan ciri yang tidak baik, dan memanfaatkan sisa yang ada untuk semisal pintu.

Informan IV menyampaikan bahwa sesuatu yang perlu diperhatikan tentang penggunaan kayu adalah keluit, yakni pembawa hawa atau pengaruh buruk. Sebagai contoh penggunaan kayu dengan ciri "buntel mayit" yang dicirikan sebagai keadaan kayu dimana di dalamnya terdapat sisa kulit kayu, akan memudahkan bagi orang yang ingin berbuat jahat untuk mengirim teluh. Hal tersebut dikaitkan dengan kisah tentang perjanjian antara mahluk halus dan manusia tentang jenis-jenis pohon yang dijadikan sebagai papan (tempat tinggal) bagi mahluk halus yang berjumlah 9 (sembilan) jenis pohon, diantaranya adalah Serut, Beringin, dan Sawo. Dikisahkan juga terdapat ilmu yang digunakan untuk memindah mahluk halus. Sehingga apabila jenis-jenis pohon tersebut ditanam di pekarangan, misalkan pohon Serut, akan mudah bagi orang yang berniat jahat untuk memindahkan mahluk halus agar bertempat tinggal pada pohon tersebut. Apabila pada halaman rumah terdapat pohon-pohon tersebut sebaiknya dipindah atau ditebang.

Ciri-ciri kayu yang tidak baik hanya berlaku untuk kayu Jati, sementara untuk kayu lain tidak demikian. Hal tersebut dikarenakan kayu Jati disebut sebagai kayu yang "sejati”, yakni dapat ditempati oleh "pulung" (kehormatan, pangkat derajat) ataupun "derupeksi" (tenung). Rumah yang ditempati Informan IV sudah berusia sekitar 30 (tiga puluh) tahun berbahan kayu Jati kuno, sehingga dinyatakan memberikan pengaruh pada kemampuan perlindungan kepada anak dan cucu, serta mendatangkan keberuntungan.

Berdasarkan informasi yang diberikan dari Informan IV, maka tema-tema yang dapat diperoleh sebagai Unit Informasi IV adalah:

1. Pantangan penggunaan kayu, yakni antara kayu Jati dan Nangka

2. Jenis-jenis kayu yang dinilai tidak baik

3. Tata cara penebangan

4. Dampak atau efek pemilihan dan penggunaan kayu, baik kayu dengan ciri yang tidak baik, maupun kayu Jati (kuno)

5. Sejarah keterkaitan dampak kayu dengan cerita tentang mahluk halus penghuni

6. Keutamaan kayu Jati

\section{Temuan Tema dari Unit Informasi V}


Unit informasi V (kelima) diperoleh di kediaman keluarga Ibu Sastrowiharjo, dengan Ibu Sastrowiharjo sebagai Informan V. Rumah Ibu Sastrowiharjo merupakan rumah warisan dari orangtua beliau dan telah ada semenjak zaman (penjajahan) Jepang dan dinyatakan belum mengalami perubahan. Sekitar tahun 2012, tiang pada rumah tersebut pernah mengalami doyong (miring), namun kembali tegak dengan sendiri setelah diajak berkomunikasi oleh Informan V. Bahan kayu yang digunakan pada rumah Informan V adalah kayu Jati. Kayu tersebut berasal dari hutan milik pemerintah di dekat Pantai Siung. Kayu tersebut diperoleh dengan jalan membeli untuk dibuat menjadi empat rumah, yakni rumah yang ditempati saat ini (Joglo), kemudian bagian belakangnya merupakan rumah Bunder, kemudian Lingkring, dan Pawon.

Berdasarkan informasi yang diberikan dari Informan $\mathrm{V}$, maka tema-tema yang dapat diperoleh sebagai Unit Informasi V adalah:

1. Asal muasal kayu dari hutan di dekat Pantai Siung, milik pemerintah

2. Perolehan kayu, dengan jalan membeli

\section{Temuan Tema dari Unit Informasi VI}

Unit informasi VI (keenam) diperoleh di kediaman keluarga Bapak Hartono, dengan Bapak Hartono sebagai Informan VI. Rumah keluarga Bapak Hartono terdiri dari rumah Bunder (sisi Barat) bersambung dengan rumah Panjang (sisi Timur). Rumah bagian barat (Bunder) didominasi oleh bahan kayu pada dinding dan rangka strukturnya, kecuali pada usuk digunakan bambu. Sementara itu, rumah bagian timur (Panjang) menggunakan rangka dan penutup dinding dari bambu. Bagian rumah sebelah barat sedang mengalami pembongkaran yang dikerjakan secara bergotong royong. Komponen yang diganti adalah cagak-cagak sudut (tiang-tiang) pada sudut rumah. Penggantian tersebut dilakukan karena usia rumah sudah mencapai sekitar 50 tahun, sementara bagian tiang pojok yang akan diganti terbuat dari kayu Akasia dinilai sudah amoh (usang).

Informan VI menyampaikan bahwa untuk tiang bagian dalam rumah yang terbuat dari kayu Jati tidak diganti. Usuk dan reng yang berbahan bambu akan diganti dengan kayu Akasia. Guna keperluan perbaikan tersebut, kayu yang disiapkan di halaman depan rumah adalah kayu Akasia yang tergolong kayu Taun. Kayu tersebut merupakan milik informan VI yang terletak di hutan Smurup yang jaraknya tidak terlalu jauh dari dusun Pringsanggar. Kayu yang diambil untuk perbaikan tersebut sesuai dengan kebutuhan. Sementara itu, menurut Informan VI, kayu Akasia memiliki ketahanan namun juga kelemahan, yakni kerentanan terhadap air. Oleh karena itu, penggantian kayu tersebut dapat dilakukan setiap 10 (sepuluh) tahun sekali.

Berdasarkan informasi yang diberikan dari Informan VI, maka tema-tema yang dapat diperoleh sebagai Unit Informasi VI adalah:

1. Alasan pemilihan kayu, yakni untuk penggantian kayu

2. Asal perolehan kayu

3. Ketahanan kayu sebagai bahan bangunan

\section{Temuan Tema dari Unit Informasi VII}

Unit informasi VII (ketujuh) diperoleh di kediaman keluarga Bapak Karyo dengan Bapak Karyo sebagai Informan VII. Informan VII menuturkan bahwa cara menebang kayu yang akan digunakan untuk membangun rumah tidak boleh sembarangan, yakni diupayakan agar arah rubuhnya harus ngaler-ngilen (utara-barat). Selain itu juga diperhatikan tentang ciri-ciri pada kayu yang dinilai 'tidak baik', berlaku untuk semua kayu adalah:

1. Sundang kongakangean, apabila pohon yang ditebang temangsang (tersangkut), atau ditebang namun ubeng-ubengan (berputar-putar) menurut ndarat (jatuhnya) 
2. Kelabang kepipit, apabila pohon yang ditebang ternyata di dalamnya ada growong (lubang)

3. Sundang angkrik ngilo luweng, apabila kayu yang ditebang rubuh dekat luweng (lubang tanah)

4. Buntel Mayit, apabila kayu yang dipeceli (dipotong) ternyata didapati klotokan (kelupasan) tepung

Untuk membuat suwunan tidak boleh sembarangan, karena ajine (kewibawaan) rumah adalah pada suwunan tersebut. Akan tetapi kayu yang digunakan untuk suwunan tidak harus kayu Jati, melainkan kayu yang disuka oleh pemilik rumah.

Menurut Informan VII, kayu Nangka dan kayu Jati tidak boleh digunakan secara bersama. Sebagai contoh, apabila pengeret menggunakan kayu Nangka, sementara blandar dari kayu Jati, akibatnya akan menimbulkan bunyi atau suara keras. Untuk itu jika menggunakan kayu Jati sebaiknya kayu Jati semua, namun apabila menggunakan kayu Nangka boleh digunakan bersama kayu jenis lain selain kayu Jati. Terdapat kayu Jati yang disebut Jati Danalaya. Jati Danalaya disebut sebagai "lurah" kayu dan tumbuhnya atau keberadaannya di Gunung Batur, Baong. Kayu Jati tersebut tidak berbeda jenis dengan kayu Jati pada umumnya, hanya saja ketika berbunga, maka gogrokan (rontokan) bunga jatuh hingga keratin.

Berdasarkan informasi yang diberikan dari Informan VII, maka tema-tema yang dapat diperoleh sebagai Unit Informasi VII adalah:

1. Tata cara dalam penebangan pohon, memperhatikan arah rubuh

2. Ciri-ciri kayu yang tidak baik dari penebangan

3. Pemilihan kayu untuk suwunan sebagai bagian terpenting rumah

4. Pantangan dalam penggunaan kayu Jati dan kayu nangka, yaitu apabila digunakan akan menimbulkan bunyi keras

5. Jenis kayu Jati Danalaya

\section{Kategorisasi Tema-tema}

Berdasarkan informasi yang diperoleh dari para Informan di lapangan, maka tema-tema temuan dapat dikategorisasikan (sebagaimana pada Tabel 1) antara lain :

1. Perolehan kayu, yang mengandung informasi pokok tentang jalan (cara) dan tempat perolehan kayu

2. Pemilihan kayu, yang mengandung informasi pokok tentang jenis-jenis kayu, cacat-cacat pada kayu, serta pantangan dalam penggunaan

3. Persyaratan dan tata cara terkait dengan penggunaan kayu, yang mengandung informasi pokok tentang proses penebangan, perhitungan, pantangan dalam penebangan, dan upacara adat yang terkait di dalamnya

4. Alasan penggunaan kayu, yang mengandung informasi pokok tentang ketahanan bahan, serta alasan yang mengandung unsur kepercayaan (religi). 
Tabel 1. Kategorisasi Tema-tema Temuan

\begin{tabular}{|c|c|c|c|c|c|c|c|c|}
\hline \multirow{2}{*}{ No. } & \multirow{2}{*}{ Tema-tema } & \multicolumn{7}{|c|}{ Sumber Informasi dari Informan } \\
\hline & & 1 & II & III & IV & $\mathrm{V}$ & $\mathrm{VI}$ & VII \\
\hline \multirow[t]{3}{*}{1.} & Perolehan kayu & & & & & & & \\
\hline & a. Jalan perolehan & - & $\sqrt{ }$ & $\sqrt{ }$ & $\sqrt{ }$ & $\sqrt{ }$ & $\sqrt{ }$ & $\sqrt{ }$ \\
\hline & b. Tempat perolehan & - & $\sqrt{ }$ & 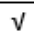 & $\sqrt{ }$ & $\sqrt{ }$ & $\mathrm{v}$ & $\sqrt{ }$ \\
\hline \multirow[t]{4}{*}{2.} & Pemilihan kayu & & & & & & & \\
\hline & a. Jenis-jenis kayu & $\sqrt{ }$ & - & $\sqrt{ }$ & $\sqrt{ }$ & $\sqrt{ }$ & $\mathrm{v}$ & $\mathrm{v}$ \\
\hline & b. Cacat-cacat kayu & $\sqrt{ }$ & $\sqrt{ }$ & - & - & - & $\sqrt{ }$ & $\sqrt{ }$ \\
\hline & c. Pantangan penggunaan & $\sqrt{ }$ & $\sqrt{ }$ & $\sqrt{ }$ & - & $\sqrt{ }$ & - & $\sqrt{ }$ \\
\hline \multirow[t]{5}{*}{3.} & Persyaratan dan tata cara & & & & & & & \\
\hline & a. Proses penebangan & - & $\sqrt{ }$ & - & - & - & $\mathrm{v}$ & $\mathrm{v}$ \\
\hline & b. Perhitungan penggunaan & $\sqrt{ }$ & $\sqrt{ }$ & - & - & - & - & - \\
\hline & c. Pantangan penebangan & - & $\sqrt{ }$ & - & - & - & - & 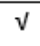 \\
\hline & d. Upacara adat & - & $\sqrt{ }$ & - & - & - & - & - \\
\hline \multirow[t]{3}{*}{4} & Alasan penggunaan & & & & & & & \\
\hline & a. Ketahanan bahan & $\sqrt{ }$ & - & - & $\sqrt{ }$ & $\sqrt{ }$ & $\sqrt{ }$ & $v$ \\
\hline & b. Religi & $\sqrt{ }$ & $\sqrt{ }$ & $\sqrt{ }$ & - & $\sqrt{ }$ & $\sqrt{ }$ & $\sqrt{ }$ \\
\hline
\end{tabular}

(Sumber: Analisis dan Olah Data oleh Penulis, 2020)

\section{Konseptualisasi berdasar Tema}

Merujuk pada kategorisasi dari temuan tema-tema tersebut, maka dapat disusun suatu kerangka konsep berdasarkan nilai-nilai (sebagaimana ditunjukkan pada Gambar 3.) sebagai berikut:

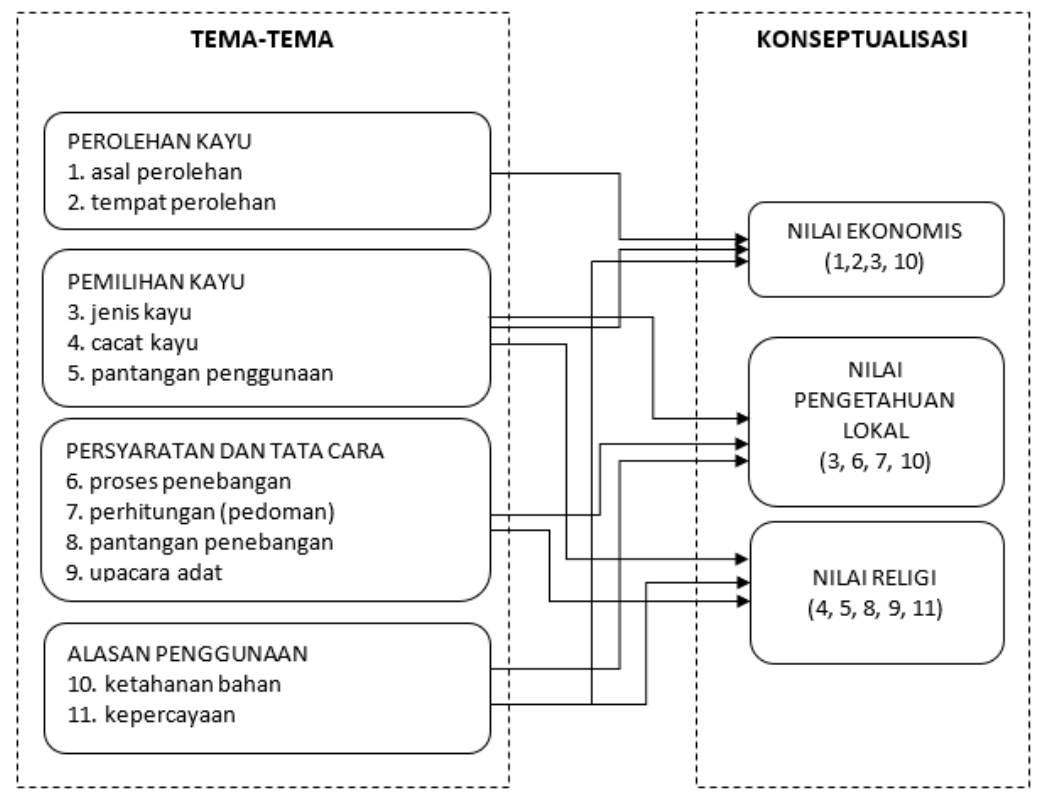

Gambar 3. Skema Induksi dari Temuan Tema

(Sumber: Analisis Data dan Informasi oleh Peneliti, 2020) 


\section{Nilai Ekonomis Penggunaan Kayu}

Tema perolehan kayu merujuk pada infromasi tentang cara dan lokasi mendapatkan bahan kayu. Kayu yang digunakan sebagai konstruksi dan elemen bangunan didapatkan dari hutan di sekitar Tepus, yang beberapa diantaranya merupakan milik "HB" atau "AB", ataupun milik sendiri. Pertimbangan penggunaan kayu juga dipengaruhi kualitas ketahanan kayu, yakni kayu Jati, untuk bagian konstruksi yang bukan utama dapat diganti material kayu lain ataupun bambu. Kayu juga diperoleh dari proses membeli baik di hutan, untuk dipilih, dipotong dan diangkut ke lokasi pembangunan, maupun sudah siap dalam bentuk batangan memanjang di pasar Dakbong. Pengangkutan kayu dari wilayah hutan dengan digotong beramai-ramai ataupun menggunakan kendaraan angkut (mobil pengangkut). Jenis kayu juga menjadi pertimbangan pilihan dalam mengkonstruksi rumah terkait dengan ketahanan terhadap kerusakan. Hal-hal tersebut menunjukkan adanya kecenderungan nilai ekonomis material kayu.

\section{Nilai Pengetahuan Lokal Penggunaan Kayu}

Tema-tema yang merujuk pada tata cara penebangan kayu, pemilihan jenis kayu berdasar kualitas ketahanan terhadap usia dan serangga, beberapa merupakan adanya pengetahuan lokal masyarakat. Sebelum penebangan pohon, dilakukan pengikisan lapisan batang bagian bawah agar sari makanan yang diserap dari tanah berkurang dan akhirnya pohon mati secara perlahan dan mengering. Hal tersebut merupakan suatu teknik untuk membantu proses pemotongan dan mendapatkan kayu yang kering. Pemilihan jenis kayu juga merupakan pengetahuan tersendiri, terutama jenis-jenis kayu yang disebut kayu tahun antara lain: Akasia, Waru, Sengon. Pengetahuan-pengetahuan tersebut secara kenyataan di masyarakat dapat berjalinan dengan nilai-nilai kepercayaan yang disandingkan, meskipun beberapa di antaranya dapat dijelaskan secara logis.

\section{Nilai Religi Penggunaan Kayu}

Tema-tema yang menunjukkan konsep religi antara lain yang memiliki keterkaitan dengan pemilihan kayu, perhitungan, pantangan, upacara adat, maupun alasan atau tujuan dari penggunaan kayu tersebut. Sebagaimana wujud arsitektur rumah tradisionalnya, maka elemen-elemen terkait yang menyusun bangunan rumah pun tidak lepas dari unsur-unsur religi yang menjadi layaknya acuan atau pedoman untuk ditaati dan diwariskan. Kepercayaan atau keyakinan tersebut seringkali beririsan dengan pengetahuan rasional, namun beberapa dapat dikatakan lebih memegang teguh sebagai tradisi yang diyakini akan membawa dampak tertentu terhadap pelaksanaan ataupun penolakannya. Seperti halnya kepercayaan tentang penunggu kayu Jati dan kayu Nangka yang tidak bisa disatukan karena akan saling bermusuhan, sehingga apabila dilanggar dan menggunakan keduanya secara bersama akan menimbulkan efek ketidaknyamanan yang ditandai pula dengan suara atau bunyi yang dihasilkan. Secara rasional, hal tersebut dijelasakan dengan alasan bahwa serangga pemakan kayu Jati dan serangga kayu Nangka apabila berpadu akan menghasilkan senyawa racun yang membahayakan kesehatan. Meskipun demikian, beberapa hal sebagaimana perhitungan, pantangan, syarat, adalah bentuk-bentuk kepercayaan yang tumbuh pada masyarakat dan terkadang dengan atau tanpa rasionalisasi akan tetap diterima selama masyarakat masih memegang tradisi dan mewariskannya.

\section{Simpulan}

Rumah Tradisional di Desa Purwodadi, Kecamatan Tepus, Kabupaten Gunungkidul, Provinsi D.I Yogyakarta mengacu pada rumah tradisional Jawa, yang dikenal dengan Omah Bunder. Material yang digunakan untuk mengkonstruksikan rumah tersebut didominasi oleh kayu pada struktur rangka maupun penutup dinding, beberapa menggunakan bambu, dan beratap genteng dari tanah liat. Berdasarkan konseptualisasi tema-tema temuan dapat diketahui bahwa fenomena penggunaan material kayu sebagai penyusun konstruksi rumah tradisional di Tepus tersebut dipengaruhi oleh beberapa hal, 
yakni: 1) nilai ekonomis yang ditunjukkan dari asal perolehan kayu dan tujuan pemilihan kayu tersebut; 2) nilai pengetahuan lokal yang diturunkan, yang mencakup pemilihan kayu, penggunaannya pada konstruksi, serta 3) nilai religi yang ditunjukkan dengan kepercayaan akan adanya penguasa kayu, pelaksanan upacara adat, aturan dan sanksi dari pelanggaran tentang penggunaan kayu.

Berdasarkan hasil penelitian, dapat dipahami bahwa fenomena penggunaan kayu pada arsitektur rumah tradisional di Tepus tidak lepas dari nilai-nilai yang dipahami dan menjadi bagian dalam kehidupan masyarakatnya baik secara jelas (tangible) sebagaimana aspek ekonomis dan pengetahuan yang rasional, maupun yang tak nampak (intangible) sebagaimana adat-istiadat dan religi. Dengan demikian, perwujudan arsitektur rumah tradisional di Tepus sebagai produk budaya dengan segenap nilai dan aspek yang mempengaruhinya, memiliki keterkaitan erat dengan kehidupan masyarakatnya.

\section{Ucapan Terima Kasih}

Penulis mengucapkan terimakasih kepada pihak Program Studi Arsitektur Universitas Widya Mataram yang telah berkenan menerima laporan hasil penelitian untuk direview dan dipublikasikan melalui Jurnal Pendapa. Penulis juga menyampaikan terimakasih kepada segenap narasumber serta rekan-rekan mahasiswa Pascasarjana Arsitektur Universitas Gadjah Mada (UGM) khususnya angkatan 2010, yang telah membersamai waktu dan berbagi pengalaman dalam melakukan proses penelitian di wilayah Tepus, Gunungkidul, Daerah Istimewa Yogyakarta.

\section{Referensi}

Anisa. (2010). Aplikasi Paradigma Naturalistik Fenomenologi dalam Penelitian Arsitektur. Jurnal NALARs, Volume 9 Nomor 1 Januari 2010: 73-82. Diambil dari https://jurnal.umj.ac.id/index.php/nalars/article/download/608/568

Badan Perencanaan Pembangunan Daerah. (2012). Sistem Informasi Profil Daerah Kabupaten Gunungkidul Tahun 2012: 27-28

Badan Pusat Statistik Kabupaten Gunungkidul. (2019). Gunung Kidul dalam Angka. Gunungkidul Regency in Figures 2019. Cetakan II, September 2019

Creswell, John W. (2013). (terj) Penelitian Kualitatif dan Desain Riset. Yogyakarta: Pustaka Pelajar

Gunawan, Undi. (2013). Fenomenologi Arsitektur; Konsep, Sejarah dan Gagasannya, Jurnal NALARs Volume 12 No 1 Januari 2013. Diambil dari https://jurnal.umj.ac.id/index.php/nalars/article/download/569/532

Haripoza, Okki Dwi. (2016). Identifikasi Perubahan Arsitektur Rumah Tradisional, Studi Kasus Permukiman Desa Kurau, Aliran Sungai Desa Kurau di Kabupaten Bangka Tengah, Provinsi Bangka Belitung, Tesis Program Studi Magister Arsitektur Program Pascasarjana Universitas Atma Jaya, Yogyakarta. Diambil dari http://e-journal.uajy.ac.id/11078/1/0MTA01927.pdf

Mixdam, Candra Bagus Sultan. (2017). Sosialisasi Adat Rasulan di Kalangan Anak-Anak pada Era Modernisasi di Daerah Playen, Gunungkidul. Jurnal Analisa Sosiologi, April 2017, 6(1): 33-41. Diambil dari https://jurnal.uns.ac.id/jas/article/view/18100

Salura, Purnama. (2001). Ber-Arsitektur: Membuat, Menggunakan, Mengalami, Dan Memahami Arstektur. Bandung: Architecture \& Communication

Sardjono, Agus Budi dan Nugroho, Satrio. (2015). Keragaman Perubahan pada Rumah Tradisional Jawa di Pedesaan, Jurnal. Modul Volume 15 Nomer 2 Tahun 2015: 142. Diambil dari https://ejournal.undip.ac.id/index.php/modul/article/view/10773 
Subroto, Tarcicius Yoyok Wahyu. (2019). Koeksistensi Alam dan Budaya dalam Arsitektur, Natural Coexsistency and Culture in Architecture, ARTEKS : Jurnal Teknik Arsitektur, Volume. 3, Nomor 2, Juni 2019. Diambil dari https://journal.unwira.ac.id/index.php/ARTEKS/article/download/60/41

Wibowo, J., Murniatmo, Gatut, dan Sukirman. (1998). Arsitektur tradisional Daerah Istimewa Yogyakarta. Direktorat Sejarah dan Nilai Tradisional, Jakarta. Diambil dari http://repositori.kemdikbud.go.id/id/eprint/8237

Wibowo, Satrio Hasto Broto. (2013). Arsitektur Omah Bunder di Desa Purwodadi, Kecamatan Tepus, Kabupaten Gunungkidul. Thesis. Universitas Gadjah Mada 